\title{
First report of Hyaloperonospora brassicae causing downy mildew on wild radish in Mexico
}

\section{Robles-Yerena $\mathbf{L}^{1}$, Leyva-Mir SG $^{2}$, Carreón-Santiago IC $^{2}$, Cuevas-Ojeda $\mathbf{J}^{2}$, Camacho-Tapia $\mathbf{M}^{3}$, Tovar-Pedraza $\mathrm{JM}^{2 *}$}

\footnotetext{
${ }^{1}$ Universidad Autónoma Chapingo, Departamento de Fitotecnia, Posgrado en Horticultura. Carretera México-Texcoco km. 38.5, Chapingo, 56230, Estado de México, Mexico.

${ }^{2}$ Universidad Autónoma Chapingo, Departamento de Parasitología Agrícola. Carretera México-Texcoco km. 38.5, Chapingo, 56230, Estado de México, Mexico.

${ }^{3}$ Colegio de Postgraduados, Campus Montecillo, Fitopatología. Carretera México-Texcoco km. 36.5, Montecillo, 56230, Estado de México, Mexico.
}

Robles-Yerena L, Leyva-Mir SG, Carreón-Santiago IC, Cuevas-Ojeda J, Camacho-Tapia M, TovarPedraza JM 2017 - First report of Hyaloperonospora brassicae causing downy mildew on wild radish in Mexico. Plant Pathology \& Quarantine 7(2), 137-140, Doi 10.5943/ppq/7/2/5

\begin{abstract}
During August and September 2016, symptoms and signs of downy mildew were observed on stems and inflorescences of wild radish (Raphanus raphanistrum) plants in field plots in Cuapiaxtla, Tlaxcala, Mexico. Based on morphological characteristics, analysis of rDNA-ITS sequences, and pathogenicity tests on wild radish plants, the causal agent was identified as Hyaloperonospora brassicae. This is the first report of $H$. brassicae causing downy mildew on $R$. raphanistrum in Mexico.
\end{abstract}

Key words - Raphanus raphanistrum - morphology - pathogenicity - sequence analysis

\section{Introduction}

Wild radish (Raphanus raphanistrum) is a widespread weed of Eurasian origin that occurs in agricultural fields, disturbed areas, and coastal beaches. This plant grows vigorously as a weed in all continents except for Antarctica (Holm et al. 1997, Warwick \& Francis 2005). With its longlived seed bank, early emergence after tilling, and annual growth habit, $R$. raphanistrum is a difficult weed to manage, especially in cereal crops (Warwick \& Francis 2005).

Hyaloperonospora parasitica and $H$. brassicae have been reported as causal agents of downy mildew on wild radish in several countries (Farr \& Rossman 2017), however, the specific identity of the pathogen in wild radish plants in Mexico has not been determined.

\section{Materials \& Methods}

\section{Sample collection}

During August and September 2016, wild radish plants showing typical symptoms of downy mildew were observed in field plots in Cuapiaxtla, Tlaxcala, Mexico. The disease incidence in the 
field was estimated to be $85 \%$. Infection resulted in a white sporulation developing on the stems, peduncles, and inflorescences (Fig. 1A-C).

\section{Morphology}

For the morphological characterization of the oomycete, slide preparations were made in lactic acid and structures were examined with a compound microscope Eclipse Ni-U (Nikon ${ }^{\circledR}$, Japan). The qualitative and quantitative morphological characteristics of 50 sporangiophores and 200 sporangia were recorded. The identification of the oomycete genus was done with the use of Constantinescu \& Fatehi (2002) specialized identification keys, while the description reported by Choi et al. (2012) was used for the determination of the species.

\section{Pathogenicity tests}

Pathogenicity was confirmed by inoculating 20 healthy wild radish plants with a sporangial suspension $\left(1 \times 10^{4}\right.$ sporangia/ml $)$. Ten non-inoculated plants served as controls. Plants were incubated in a dew chamber at $20{ }^{\circ} \mathrm{C}$ for $48 \mathrm{~h}$, and then were maintained in a glasshouse at temperatures ranging between 20 and $25{ }^{\circ} \mathrm{C}$ and relative humidity at $80 \%$. The entire experiment was conducted twice.

\section{DNA extraction, PCR amplification and sequencing}

To confirm the identity of the oomycete, genomic DNA was extracted from mycelia using a DNeasy Plant Mini Kit (Qiagen ${ }^{\circledR}$, USA) according to the manufacturer protocol. The quality of the DNA was verified by electrophoresis in a $1.2 \%$ agarose gel. DNA concentrations were quantified using a NanoDrop Lite Spectrophotometer (Thermo Scientific, USA) and the samples were diluted to $50 \mathrm{ng} / \mu \mathrm{l}$ for PCR reaction. The rDNA internal transcribed spacer region (ITS1-5.8S-ITS2) of a representative isolate was amplified using the ITS5 and ITS4 primers, and PCR conditions, as described by White et al. (1990). The amplified PCR product was purified using the Wizard SV Gel and PCR Clean-Up System (Promega ${ }^{\circledR}$, USA), and sequenced directly. The resulting sequence was deposited in GenBank (Accession No. KY563710) and was compared with other ITS sequences.

\section{Results}

Microscopic examinations of fresh material revealed sporangiophores that were hyaline, straight, 280 to $610 \mu \mathrm{m}$ long. Sporangiophores (Fig. 1D) ended with sporangia that were hyaline, subglobose-ovoid, and measured 17.5 to $25.5 \times 16.2$ to $24.3 \mu \mathrm{m}$ (Fig. 1E-F). No oospores were observed. Morphological characteristics were most similar to the description of Hyaloperonospora brassicae reported by Choi et al. (2012). A voucher specimen was deposited in the Herbarium of the Department of Agricultural Parasitology at the Chapingo Autonomous University (Texcoco, Estado de México, Mexico) as "UACH-H179".

BLASTn analysis of the sequence showed a $100 \%$ similarity with those of $H$. brassicae from Spain (Accession Nos. EU049273 and EU049278).

All inoculated plants developed white sporulation within 6 to 8 days after inoculation. Disease symptoms were similar to those observed in the field, whereas no symptoms were observed on the control plants. Microscopic examinations of symptomatic tissues confirmed the presence of the pathogen, fulfilling Koch's postulates.

\section{Discussion}

The results of the present study confirm that $H$. brassicae is the causal agent of downy mildew on wild radish in Mexico. This oomycete has been previously reported causing downy mildew on wild radish in Czech Republic, Germany, Spain, Bulgaria, Norway, Poland, and Switzerland (Farr \& Rossman 2017).

The genus Hyaloperonospora is the third largest genus of downy mildews, containing more that 100 species, which can infect economically important Brassicaceae crops such as horseradish (Armoracia rusticana), mustard greens (Brassica juncea), rapeseed (B. napus), tatsoi (B. narinosa), 
cabbage (B. oleracea var. capitata), cauliflower (B. oleracea var. botrytis), Chinese cabbage (B. rapa), arugula (Eruca sativa), wasabi (Eutrema japonicum), watercress (Nasturtium officinale), and radish (Raphanus sativus) (Thines \& Choi 2016). In Mexico, H. brassicae can be a serious threat to the production of radish, cabbage, and cauliflower, which are crops commonly produced where infected wild radish plants were found.
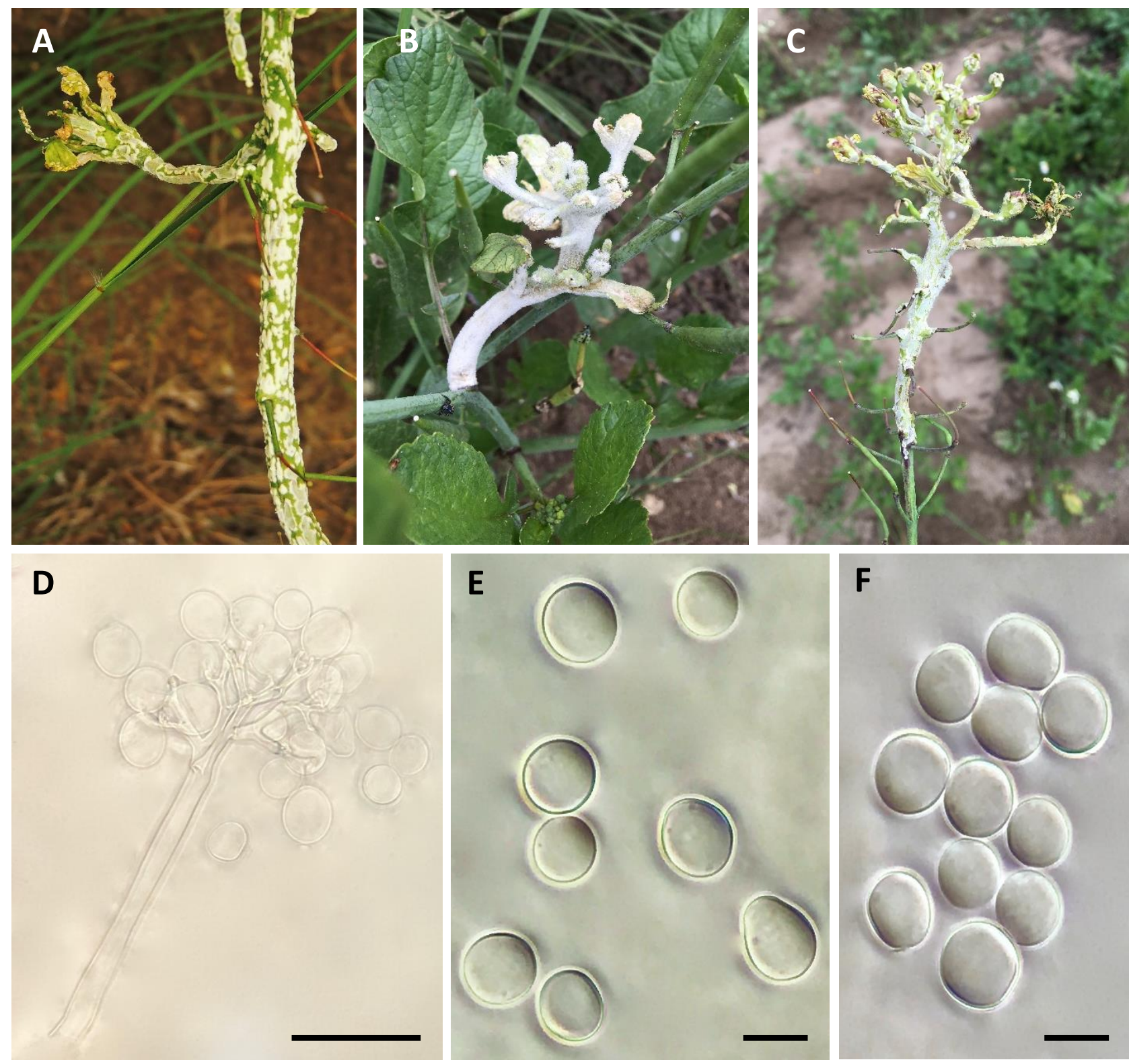

Fig 1 - Hyaloperonospora brassicae on wild radish; A-C Symptoms and signs on stems and inflorescences, D Sporangiophore with sporangia, E-F Sporangia. - Bars $=\mathrm{D}=50 \mu \mathrm{m}, \mathrm{E}-\mathrm{F}=20$ $\mu \mathrm{m}$.

\section{References}

Choi YJ, Kim JY, Park JH, Shin HD. 2012 - First report of tatsoi downy mildew caused by Hyaloperonospora brassicae in Korea. Plant Disease 96, 1703.

Constantinescu O, Fatehi J. 2002 - Peronospora-like fungi (Chromista Peronosporales) parasitic on Brassicaceae and related hosts. Nova Hedwigia 74, 291-338.

Farr DF, Rossman AY. 2017 - Fungal Databases, Systematic Mycology and Microbiology Laboratory, ARS, USDA. Retrieved June 30, from http://nt.ars-grin.gov/fungaldatabases/. 
Holm L, Doll J, Holm E, Pancho J, Herberger J. 1997 - World weed. Natural histories and distribution. Wiley, New York, USA.

Thines M, Choi YJ. 2016 - Evolution, diversity, and taxonomy of the Peronosporaceae. With focus on the genus Peronospora. Phytopathology 106, 6-18.

Warwick SI, Francis A. 2005 - The biology of Canadian weeds. 132. Raphanus raphanistrum L. Canadian Journal of Plant Science 85, 709-733.

White TJ, Bruns T, Lee S, Taylor JW. 1990 - Amplification and direct sequencing of fungal ribosomal RNA genes for phylogenetics. In: Innis MA, Gelfand DH, Sninsky JJ, White TJ (Eds.) PCR protocols: a guide to methods and applications. California, USA, Academic Press. pp 315-322. 